\title{
PERUBAHAN MORFOLOGI KATUP MITRAL PADA DEMAM REMATIK AKUT DAN PENYAKIT JANTUNG REMATIK
}

\author{
Dede Jumatri Tito ${ }^{1)}$, Mefri Yanni ${ }^{2)}$ \\ ${ }^{1}$ Fakultas Kedokteran, Univrsitas Andalas, Jl. Perintis Kemerdekaan No. 14D, Sawahan Timur, Padang \\ email : drdede03@gmail.com \\ ${ }^{2}$ Fakultas Kedokteran, Univrsitas Andalas, Jl. Perintis Kemerdekaan No. 14D, Sawahan Timur, Padang \\ email : $\underline{\text { mefriyanni@gmail.com }}$
}

Submitted: 10-04-2020,Reviewer: 11-04-2020,Accepted: 20-04-2020

\begin{abstract}
Rheumatic fever and rheumatic heart disease remains a significant cause of cardiovascular disease in the world, especially in industrial countries and developing countries. Rheumatic heart disease is the most serious complication of rheumatic fever which is characterized by the occurrence of heart valve defects are most of the mitral valve, aortic and tricuspid followed. Valvulitis or inflammatory process in the tissue of the mitral valve causing edema of the valve leaflets and chordae tendineae, causing disruption valve closure is causing mitral regurgitation. Eventually fibrosis and calcification of the valve that causes stiffness and the valve leaflets into mitral valve stenosis. The earliest possible introduction of cardiac involvement in rheumatic heart disease is an important part in the prevention of further heart damage.
\end{abstract}

Keywords: rheumatic heart disease, mitral valve

\begin{abstract}
Abstrak
Demam rematik dan penyakit jantung rematik masih menjadi penyebab penyakit kardiovaskular yang signifikan di dunia, terutama di negara industri dan negara berkembang. Penyakit jantung rematik merupakan komplikasi yang paling serius dari demam rematik yang ditandai dengan terjadinya cacat katup jantung yang terbanyak mengenai katup mitral, diikuti aorta dan tricuspid. Valvulitis atau proses inflamasi pada jaringan katup mitral menyebabkan edema pada daun katup dan korda tendinea sehingga menyebabkan gangguan penutupan katup yang menyebabkan regurgitasi mitral. Lama kelamaan terjadi fibrosis dan kalsifikasi pada katup yang menyebabkan kekakuan daun katup dan menjadi stenosis katup mitral. Pengenalan sedini mungkin keterlibatan jantung pada penyakit jantung rematik merupakan bagian yang penting dalam pencegahan terjadinya kerusakan jantung lebih lanjut.
\end{abstract}

Kata kunci : penyakit jantung rematik, katup mitral. 


\section{PENDAHULUAN}

Demam Rematik (DR) dan Penyakit Jantung Rematik (PJR) masih menjadi penyebab penyakit kardiovaskular yang signifikan di dunia. Kejadian DR akut dan PJR di negara industri menurun selama lima dekade terakhir, namun PJR masih tetap menjadi masalah di negara berkembang hingga permulaan abad ke- 21 yang mengenai anak-anak dan dewasa muda pada usia produktif. ${ }^{1}$

\section{Dalam laporan World Health} Organization (WHO) Expert Consultation Geneva pada tahun 2000, dilaporkan angka kematian akibat PJR bervariasi di setiap negara, mulai dari 1,8 per 100.000 penduduk di Amerika hingga 7,6 per 100.000 penduduk di Asia Tenggara. ${ }^{1}$ Prevalensi DR di negara berkembang berkisar antara 7,9 sampai 12,6 per 1000 anak sekolah. Data terakhir mengenai prevalensi demam rematik di Indonesia tahun 1981-1990 di dapatkan sebesar 0,30,8 per 1000 anak sekolah dengan rentang usia 5-15 tahun. ${ }^{2}$

Penyakit jantung reumatik merupakan komplikasi yang paling serius dari demam reumatik. Sebanyak 39\% dari pasien dengan demam rematik akut (DRA) akan berkembang menjadi pankarditis yang disertai dengan insufisiensi katup, gagal jantung, perikarditis, dan bahkan kematian. Pada penyakit jantung rematik kronik, pasien dapat mengalami stenosis katup dengan berbagai derajat regurgitasi, dilatasi atrium, aritmia, dan disfungsi ventrikel. ${ }^{1,2}$

Keterlibatan jantung menjadi komplikasi terberat dari DRA dan menyebabkan morbiditas dan mortalitas yang signifikan. Morbiditas akibat gagal jantung dan endokarditis sering terjadi pada penderita PJR dengan sekitar 1,5\% penderita karditis rematik akan meninggal per tahunnya. Keterlibatan endokardium akan menyebabkan valvulitis rematik. Valvulitis paling sering mengenai katup mitral sebesar $48 \%$, diikuti oleh kombinasi katup mitral dan aorta sebesar 42\%, kombinasi katup mitral, aorta dan trikuspid sebesar $4 \%$, katup aorta saja sebesar $2 \%$, dan kombinasi lainnya sekitar 4\%.,

Deteksi dini terhadap demam rematik yang menimbulkan komplikasi pada jantung khsusnya terhadap kerusakan katup menjadi bagian penting dalam mencegah terjadinya kerusakan jantung lebih lanjut. Dalam tinjauan pustaka dasar ini akan dibahas mengenai perubahan morfologi katup mitral pada penyakit jantung reumatik.

\section{EPIDEMIOLOGI}

Penyakit jantung rematik merupakan penyakit jantung sebagai akibat adanya gejala sisa (sekuele) dari DR. ${ }^{4}$ Demam rematik jarang terjadi sebelum usia 5 tahun dan setelah usia 25 tahun, dengan insiden tertinggi pada 5-14 tahun terutama di negara tidak berkembang atau sedang berkembang dimana antibiotik tidak secara rutin digunakan untuk pengobatan faringitis. ${ }^{4,5}$

Pada negara maju maupun negara berkembang, faringitis dan infeksi kulit merupakan infeksi yang paling sering disebabkan oleh streptokokus grup A, bakteri yang paling sering menyebabkan faringitis, dengan insiden puncak pada anak usia 5-15 tahun. Faringitis streptokokal jarang terjadi pada 3 tahun pertama kehidupan dan di usia lanjut. Diperkirakan sebagian besar anak-anak mengalami 1 episode faringitis per tahun, dimana $15-20 \%$ disebabkan oleh streptokokus grup A dan hampir $80 \%$ disebabkan oleh virus patogen. ${ }^{4,5,6}$

Manifestasi demam rematik akut yang berhubungan dengan morbiditas dan mortalitas jangka panjang adalah karditis, dengan angka mencapai 30\%-70\% dari semua kasus demam rematik akut. Walaupun secara garis besar demam rematik akut menyebabkan pankarditis, yang paling dominan dan abnormalitas paling penting adalah valvulitis, terutama regurgitasi mitral dan atau aorta. Sekitar $80 \%$ pasien mengalami karditis pada 2 
minggu pertama setelah onset demam rematik akut. tingkat keparahan dari karditis dan regurgitasi katup akan berkurang seiring dengan berkurang nya proses peradangan yang terjadi. ${ }^{5,6}$

Regurgitasi mitral terjadi pada $95 \%$ pada pasien karditis rematik akut yang merupakan abnormalitas jantung dominan pada pasien demam rematik akut. Pada regurgitasi mitral terjadi kombinasi dari dilatasi annulus, elongasi kordae yang menyebabkan gangguan penutupan katup, prolap katup anterior dan yang jarang terjadi flail daun katup mitral. ${ }^{5,6}$

Regurgitasi mitral kronik pada penyakit jantung rematik umumnya terjadi pada anak-anak dan dewasa muda, sedangkan stenosis mitral terjadi pada pasien dengan usia dekade 4 sampai 6 . Stenosis mitral tidak terjadi pada episode akut demam rematik. Stenosis biasanya terjadi setelah 15-40 tahun setelah onset demam rematik akut. seiring dengan bertambahnya waktu, terjadi proses fibrosis, retraksi, kekakuan katup, fusi komisura, pemendekan kordae yang akan menyebabkan perubahan dari regurgitasi menjadi stenosis katup. ${ }^{4,5}$

\section{STRUKTUR KATUP MITRAL NORMAL}

Katup mitral memiliki dua daun katup yaitu anterior dan posterior yang terdiri dari tiga scallop, P1, P2, P3 (Gambar 1a). Kedua daun katup menempel pada annulus mitral pada basal, sedangkan beberapa korda tendinea muncul dari permukaan ventrikel dan bagian distal menempel ke muskulus papilaris. Bentuk kompleks ini memungkinkan keseimbangan kekuatan untuk mempertahankan aliran darah searah melalui katup mitral. Struktur penampang daun katup mitral normal adalah analog dengan katup aorta, dengan tiga lapisan jaringan yaitu atrialis, spongiosa, fibrosa / ventrikularis (Gambar 1) dengan ketebalan, karakteristik sel, komposisi matriks dan fitur biomekanik yang berbeda-beda. Lapisan atrialis ditutupi dengan endotelium dan berisi lapisan jaringan ikat subendothelial yang terdiri dari kolagen lamellar dan lapisan elastin, yang memanjang dari endokardium atrium kiri ke daun katup. Keberadaan miosit atrium kiri dan sel-sel otot polos yang berdekatan dengan ujung saraf secara sementara dapat memodulasi kekakuan daun katup dan deformasi selama penutupan katup. Lapisan dibawah atrialis adalah spongiosa, yang berisi kolagen longgar dan kaya glikosaminoglikan. Lapisan ini lebih tipis pada annulus mitral dan semakin tebal ke ujung daun katup. ${ }^{4,6}$

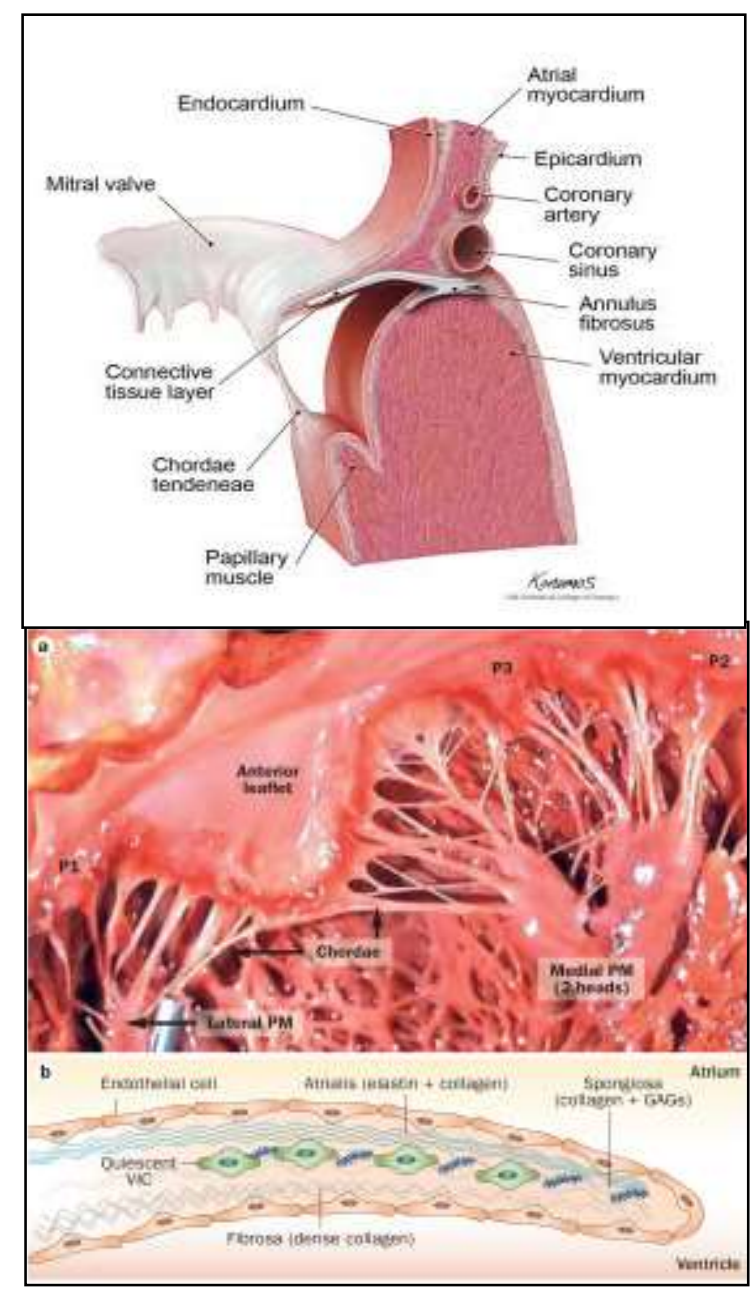

Gambar 1. Struktur katup mitral. ${ }^{4}$

Lapisan fibrosa terhubung ke annulus mitral dan menghadap ke ventrikel kiri. Lapisan ini terutama terdiri dari dari serat kolagen yang tersusun sejajar ke arah tepi daun katup. Pada sisi insersi korda, terdapat transisi fibrosa dari struktur 
kolagen planar ke kolagen silinder korda. Korda tendinea terdiri dari inti kolagen silinder dalam selubung elastin, dan memiliki sifat viskoelastik. Daun katup terdiri dari sel-sel yang memiliki fitur unik dan tetap mempertahankan homeostasis katup. Daun katup ditutupi oleh lapisan sel endotel pada kedua sisi atrium dan ventrikel. Lapisan subendotelial mengandung sel interstitial katup (valvular interstitial cells/VIC) yang berasal dari sel endotel endokardial. ${ }^{4,7}$

\section{PERUBAHAN MORFOLOGI PADA FASE AKUT}

Infeksi Streptokokus $\beta$ hemolitikus grup A memiliki hubungan dengan terjadinya DRA. Demam rematik merupakan respons autoimun terhadap infeksi Streptokokus $\beta$ hemolitikus grup A pada tenggorokan. Respon manifestasi klinis dan derajat penyakit yang timbul ditentukan oleh kepekaan genetik host, keganasan organisme dan lingkungan yang kondusif. Mekanisme patogenesis yang pasti sampai saat ini tidak diketahui, mimikri molekular menjadi salah satu teori patogenesis terjadinya DRA dimana terjadi respon melawan infeksi mikroba, yang bereaksi silang dengan antigen-antigen host dan terjadinya reaksi autoimun, yang dapat menyebabkan inflamasi pada jaringan host. ${ }^{8,10,11}$

Streptokokus grup A merupakan mikroorganisme penghasil sejumlah antigen-antigen somatik dan ekstraselular. Jaringan tubuh tertentu pada manusia memiliki kesamaan antigenik terhadap antigen tersebut dan menyebabkan antibodi yang dihasilkan untuk melawan antigen streptokokus mengalami reaksi silang dengan antigen-antigen jaringan host sehingga menghasilkan reaksi autoimun. Limfosit $\mathrm{T}$ memegang peranan dalam patogenesis penyakit ini dan ternyata tipe protein M dari Streptokokus grup A yang mempunyai potensi reumatogenik. Protein M merupakan salah satu determinan virulensi bakteri, strukturnya homolog atau mirip dengan miosin kardiak dan molekul alpha-helical colied coil, seperti tropomiosin, keratin dan laminin. Laminin merupakan matriks protein ekstraseluler yang dieksresikan oleh sel endotelial katup jantung dan bagian integral dari struktur katup jantung. Protein $\mathrm{M}$ akan mengalami reaksi silang dengan jaringan tubuh manusia terutama katup jantung karena protein ini memiliki struktur asam amino yang sama. $9,10,12$

Superantigen Streptokokal adalah glikoprotein unik yang disintesis oleh bakteri dan virus yang dapat berikatan dengan major histocompatibility complex molecules dengan nonpolymorphic $V b$ chains dari T-cell receptors. Pada kasus Streptokokus banyak penelitian yang memfokuskan pada peranan superantigenlike activity dari fragmen protein $\mathrm{M}$ dan juga streptococcal progenic exitoxin, dalam patogenesis DRA. ${ }^{10,15}$

Reaksi autoimun terhadap antigen Streptokokus memegang peranan dalam terjadinya DRA pada orang yang rentan. Sekitar $0,3-3 \%$ individu yang rentan terhadap infeksi faringitis Streptokokus berlanjut menjadi DRA. ${ }^{13},{ }^{16}$ Infeksi streptokokus dimulai dengan ikatan permukaan bakteri dengan reseptor spesifik sel host dan melibatkan proses spesifik seperti perlekatan, kolonisasi dan invasi. Manifestasi klinis demam rematik akut terjadi 1 sampai 3 minggu setelah faringitis streptokokus, dimana antigen dari streptokokus mengaktifasi sistem imum sehingga terbentuklah antibodi antistreptokokus (gambar 2). Tubuh membentuk antibodi terhadap antigen streptokokus yang berupa karbohidrad dan protein $\mathrm{M}$, dan kemudian bereaksi silang dengan protein jantung sehingga terjadi pankarditis berupa inflamasi pada myokardium, perikardium dan endokardium. ${ }^{11,12,17}$

Pada fase akut, individu dengan resiko tinggi menunjukkan respon imun tinggi terhadap karbohidrat grup A dan protein M. Antibodi spesifik Streptococcus 
menyerang jaringan jantung dan terjadi reaksi silang dengan protein alpha helical seperti miosin dan laminin, yang menyebabkan kerusakan jaringan dan memicu terjadinya proses inflamasi di miokard dan katup jantung yang dikenal dengan miokarditis dan valvulitis. Inflamasi menyebabkan peningkatkan ekspresi molekul seperti VCAM-1 yang memfasilitasi penarikan sel ke lokasi inflamasi. Progresifitas ini dimediasi oleh sel $\mathrm{T}$ dan makrofag. Sel $\mathrm{T}$ mengenali antigen sendiri yaitu miosin. Miosin merupakan protein intraseluler, dan disekuestrasi dari sistem imun. Sel T ini mengalami reaksi silang dengan epitop protein $M$ Streptococcal. Kemiripan molekular antara miosin (yang banyak ditemukan di miokardium), dan laminin (yang banyak ditemukan di katup), menjadi hipotesis yang dapat menjelaskan respon inflamasi yang ditemukan pada miokard dan katup jantung. ${ }^{13,14}$

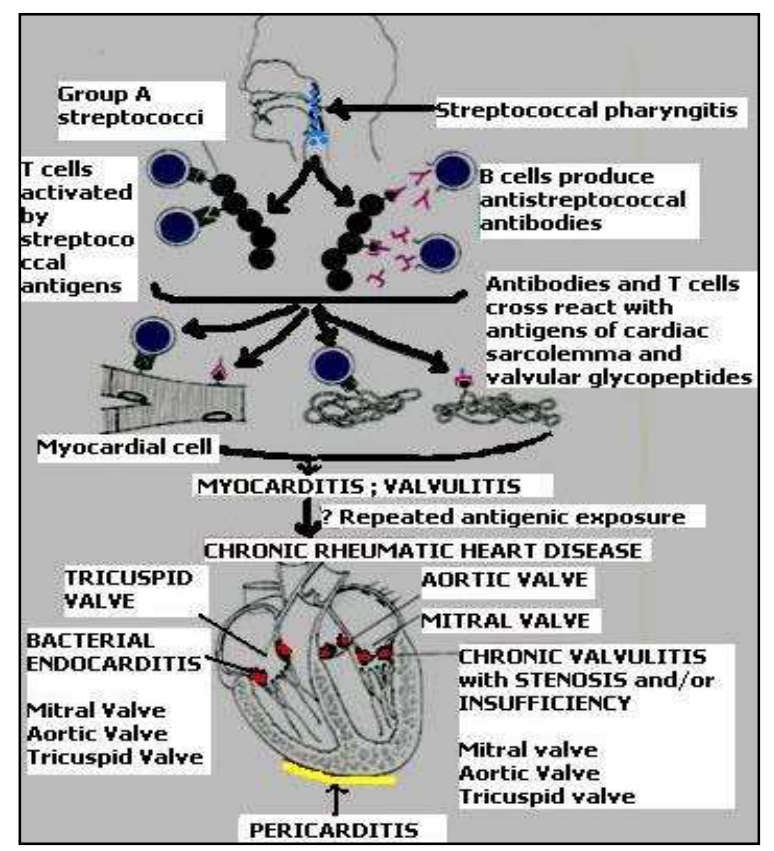

Gambar 2. Perjalanan infeksi Streptokokus Beta Hemolitikus grup A. ${ }^{15}$

Inflamasi endotel pada katup memungkinkan sel $\mathrm{T}$ untuk memasuki jaringan katup dan berproliferasi menghasilkan reaksi inflamasi lebih lanjut dan merusak katup. Inflamasi sering ditemukan secara langsung pada endotel katup dengan meningkatnya Vascular cell adhesion molecule-1 (VCAM-1) (gambar 3). Aktivasi VCAM-1 pada endotelium merupakan langkah awal penting terjadinya kerusakan katup, edema, dan infiltrasi sel $\mathrm{T}$ yang reaktif terhadap protein M Streptokokus, dan juga terhadap protein host dan Streptokokus lainnya. ${ }^{8,14,16}$

Katup jantung rentan untuk diserang oleh sistem imun yang diaktifasi oleh VCAM-1 pada endotel katup yang mencetuskan infiltrasi seluler lebih lanjut. ${ }^{18}$ Sel T yang responsif terhadap protein $\mathrm{M}$ menginfiltrasi katup melewati endotel katup yang diaktivasi oleh ikatan antistreptokokal karbohidrat dengan pelepasan TNF dan interleukin ${ }^{1}$. Reaksi silang antibodi awal terhadap karbohidrat grup A yang menyerang endotel katup dengan aktifasi VCAM-1 akan dilanjutkan dengan infiltrasi sel $\mathrm{T}$ pada katup penderita demam rematik dengan karditis, yang spesifik terhadap protein M Streptokokus dan myosin, dan juga epitop homolog lainnya (gambar 3). ${ }^{8,16}$

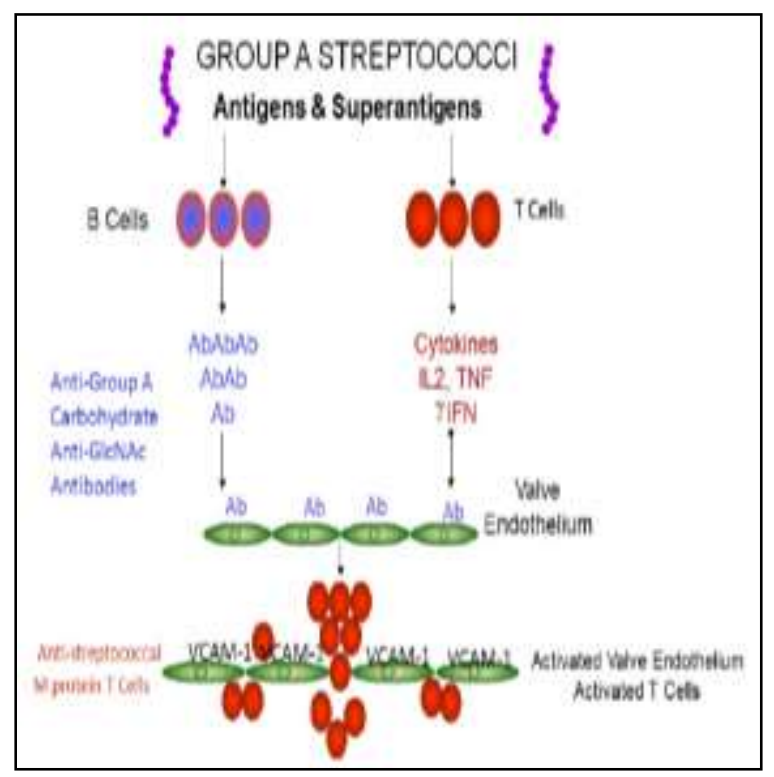

Gambar 3. Diagram ilustrasi respon sel B dan sel T terhadap antigen dan superantigen Streptokokus grup A pada karditis rematik. ${ }^{14}$ 
Pada tahap selanjutnya, setelah terjadi kerusakan membran dasar laminin pada endotel katup, jaringan dalam katup terbuka dan terjadi respon imun lebih lanjut dengan terbentuknya antibodi terhadap jaringan dalam katup seperti kolagen, elastin dan vimentin. (gambar.4) Martin dkk pada tahun 2008 telah menunjukkan bahwa kolagen dari jaringan dalam katup yang rusak merupakan target antigen yang penting. Terjadi peningkatan antikolagen antibodi pada pasien demam rematik akut dan secara signifikan lebih tinggi pada pasien yang mengalami karditis jika dibandingkan dengan tanpa karditis. Antibody terhadap kolagen tersebut spesifik dan tidak mengalami reaksi silang dengan antigen lain. ${ }^{15,18}$

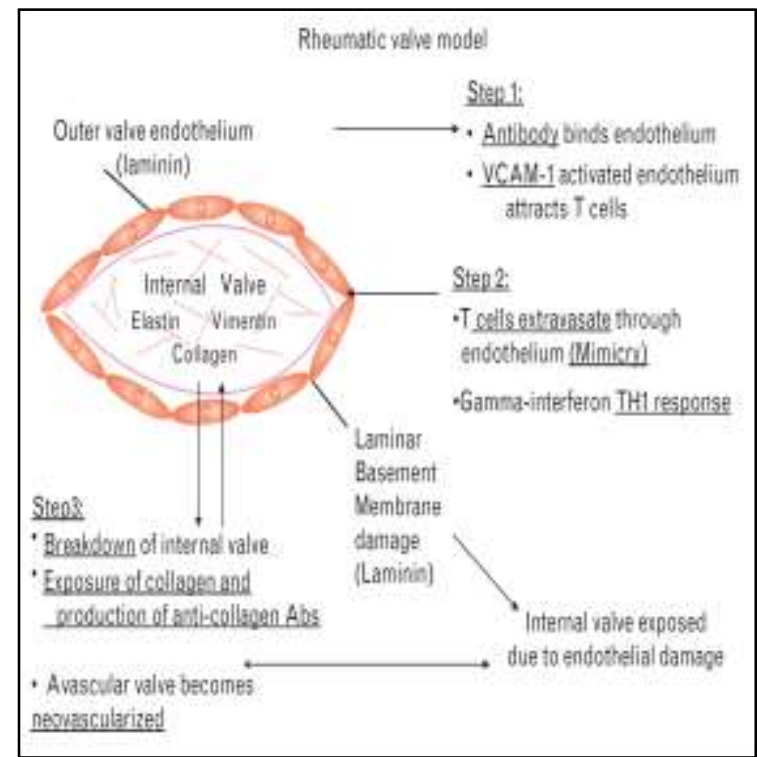

Gambar 4. Diagram tahapan mimikri molekular pada demam rematik akut dan penyakit jantung rematik. ${ }^{17}$

Neovaskularisasi yang terbentuk menunjukkan respon imun berulang dan sebagai tanda proteksi dari autoantibodi yang memasuki jaringan dalam katup sebelumnya. Pengulangan infeksi streptokokus akan menyebabkan infiltrasi limfosit lebih lanjut melalui daerah-daerah yang mengalami neovaskularisasi. Pada progresifitas PJR, respon imun pada katup akan berlanjut sampai menyebar dan mengenali komponen katup lainnya seperti vimentin dan kolagen. Peristiwa inilah yang akan menyebabkan kerusakan lebih lanjut pada katup melalui induksi pembentukan antibodi spesifik terhadap kolagen yang menyerang jaringan internal katup dan tidak bereaksi silang. ${ }^{16,17}$

\section{A. Gambaran Mikroskopik}

Secara histologi, daun katup menunjukkan penebalan yang disebabkan oleh edema dan neovaskularisasi. Pada garis penutupan katup, terdapat vegetasi yang terdiri dari fibrin. Reaksi seluler dari daun katup biasanya ditemui sel Aschoff, sel Anitschkow dan sel inflamasi kronis (gambar 5). Dibawah lapisan fibrin terdapat sel Anitschkow dan sel Aschoff dalam jumlah yang banyak. ${ }^{3,19}$

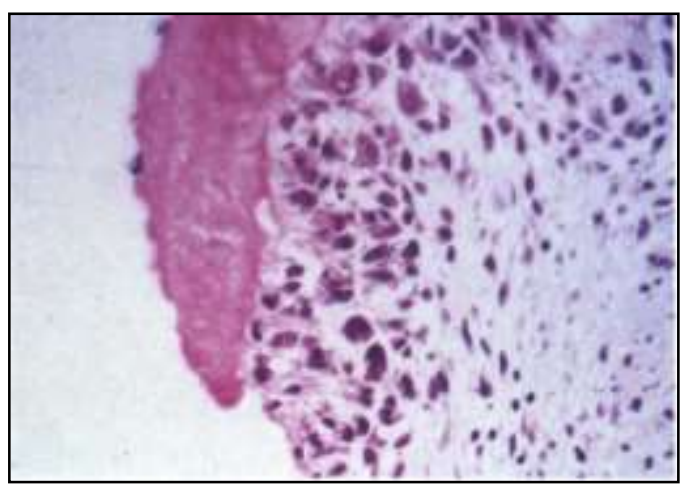

Gambar 5. Gambaran mikroskopik katup mitral pada demam rematik akut. ${ }^{3}$

Badan Aschoff ini terdiri dari fokus-fokus eosinofil yang menelan kolagen dan dikelilingi limfosit, terutama sel $\mathrm{T}$ dan terkadang sel plasma dan makrofag besaryang disebut sel Anitschkow, yang merupakan patognomonik dari demam rematik. Sel yang berbeda ini memiliki sitoplasma yang berlimpah dengan nukleus sentral bulatpanjang dimana kromatin berada ditengah, ramping, seperti pita bergelombang yang disebut caterpillar cel atau sel Anitschkow (Gambar 6). ${ }^{6,7}$

Selama fase akut, inflamasi difus dan badan Aschoff dapat ditemukan pada ketiga lapisan dari jantung, perikardium, miokardium dan endokardium yang 
disebut sebagai pankarditis. Pada perikardium, inflamasi diikuti oleh eksudat fibrin atau serofibrin sehingga diistilahkan sebagai pericarditis bread and butter yang biasanya akan bersih tanpa sekuele. Pada miokarditis, badan Aschoff tersebar luas pada jaringan intersisial dan perivaskular. Keterlibatan terus-menerus endokardium dan katup sisi kiri oleh fokus inflamasi, menghasilkan nekrosis fibrinoid di dalam kuspis atau sepanjang korda tendinea, dan juga bisa ditemui vegetasi kecil berukuran 1-2 mm yang disebut veruka di sepanjang garis penutupan katup. ${ }^{6,20}$

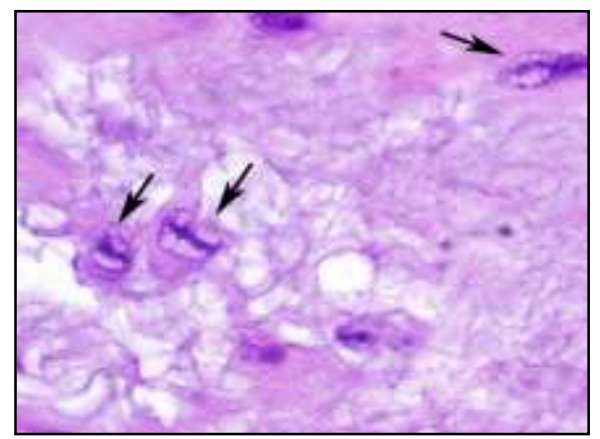

Gambar 6. Sel Anitschkow yang terdapat di bagian tengah Badan Aschoff. 6,7

Pada miokardium terdapat fragmentasi serabut kolagen, infiltrasi limfosit, dan degenerasi fibrinoid dan diikuti dengan nodul Aschoff di miokard yang merupakan patognomonik DRA. Nodul Aschoff terdiri dari area nekrosis sentral yang dikelilingi limfosit, sel plasma, dan sel mono dan multinukleus yang besar (gambar.7). Proses penyembuhan valvulitis memulai pembentukan granulasi dan fibrosis daun katup dan fusi korda tendinea yang mengakibatkan stenosis katup. ${ }^{16,17}$

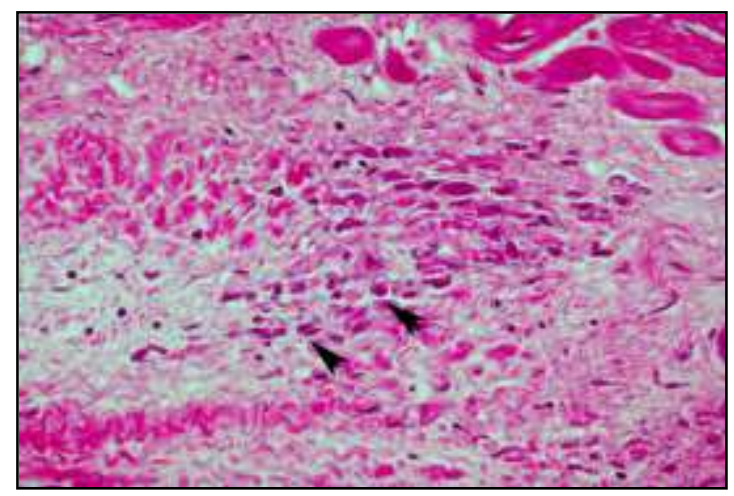

Gambar 7. Badan Aschoff.

\section{B. Gambaran Makroskopik}

Secara makroskopik, pada valvulitis mitral terjadi pemanjangan korda tendinae ataupun ruptur, dengan prolaps daun katup anterior, dilatasi anulus, gangguan koaptasi katup dan terjadi mitral regurgitasi. Perikarditis sering terjadi dan perikarditis fibrinosa kadang-kadang dapat ditemukan. Peradangan perikard biasanya sembuh setelah beberapa saat tanpa sekuele klinis yang bermakna, dan jarang menyebabkan tamponade. Pada keadaan fatal, keterlibatan miokard menyebabkan dilatasi seluruh ruang jantung. ${ }^{3,16,17}$

\section{PERUBAHAN MORFOLOGI PADA FASE AKUT}

\section{A. Gambaran Mikroskopik}

Secara mikroskopis terdapat fibrosis difus dan terdapat neovaskularisasi yang mengurangi lapisan awal dan susunan daun katup avaskular. Badan aschoff digantikan oleh jaringan parut fibrosis sehingga bentuk diagnostik lesi ini jarang ditemukan pada spesimen jaringan autopsi dari pasien dengan PJR kronik (gambar.8). Kalsifikasi juga merupakan manifestasi yang umum terjadi pada fase kronis. Sebelumnya, mekanisme seluler dari proses kalsifikasi tersebut dianggap disebabkan oleh akumulasi kalsium secara pasif di sepanjang permukaan daun katup, tetapi pada tahun 2005, Rajamannan dkk menyimpulkan bahwa mekanisme kalsifikasi pada katup mitral rematik mirip dengan mekanisme pembentukan tulang skeletal dan terjadi di daerah neovaskularisasi, yang dirangsang oleh prosses inflamasi aktif dan pelepasan Vascular Endothelial Growth Factor. 6,7,20

Rajamannan dkk, meneliti dengan melakukan pemeriksaan langsung pada jaringan katup mitral pasien dengan PJR, secara imunohistokimia dan juga menggunakan Microcomputed Tomography untuk menilai mineralisasi yang ada pada jaringan katup. Pada 
Imunohistokimia, tampak fokus-fokus kalsifikasi disekitar daerah neovaskularisasi pada jaringan katup yang rusak dan micro $\mathrm{CT}$, tampak kalsifikasi kompleks pada jaringan katup (gambar 9). ${ }^{18,20}$

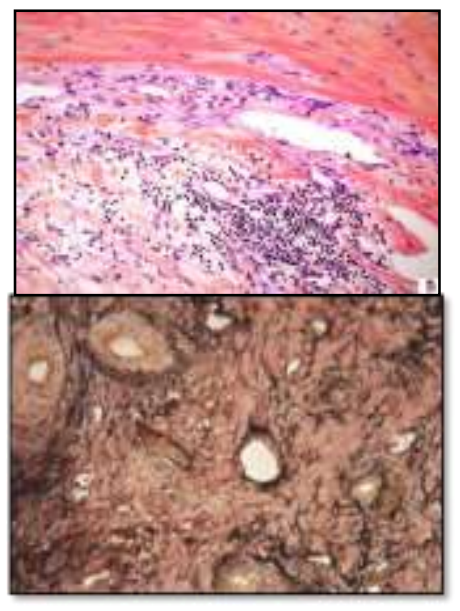

Gambar 8. Katup mitral pada fase kronis penyakit jantung rematik. Tampak peningkatan jumlah pembuluh darah. ${ }^{6}$

Deckers dkk menyatakan bahwa VEGF mengatur proses kalsifikasi dengan menarik sel endotel dan dengan merangsang sel osteoblast. VEGF dilokalisasi pada sel-sel di daerah inflamasi pada jaringan fibrosa katup, khususnya sel makrofag dan myofibroblast yang akan berproliferasi mensintesis protein matriks tulang. ${ }^{19,20}$

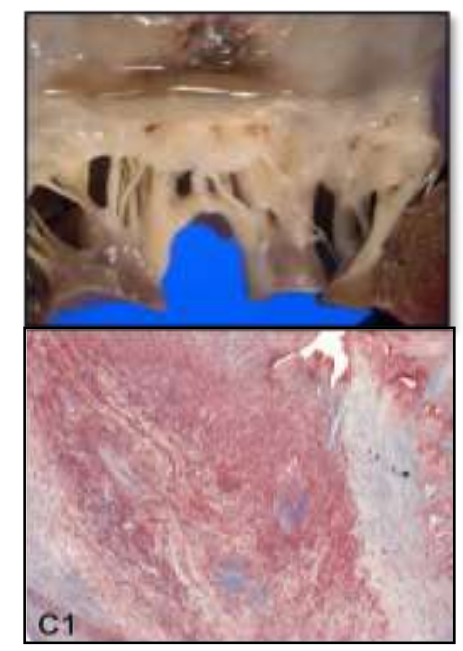

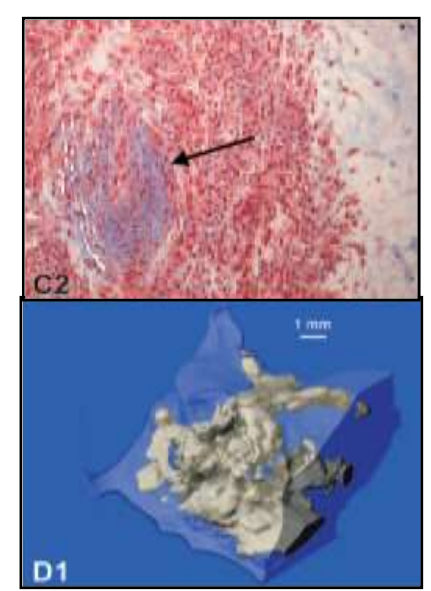

Gambar 9. Pemeriksaan imunohistokimia yang menggambarkan kalsifikasi pada daerah disekitar neovaskularisasi (atas), Micro $C T$ memperlihatkan kalsifikasi secara 3 dimensi didalam jaringan katup

$$
\text { (bawah) })^{20}
$$

\section{B. Gambaran Makroskopik.}

Penyakit jantung rematik kronis memiliki karakteristik inflamasi kronis dan fibrosis. Daun katup menjadi menebal, retraksi dan menyebabkan deformitas permanen. Perubahan anatomi utama pada katup mitral adalah penebalan daun katup, fusi komisura dan pemendekan serta penebalan dan fusi korda tendinea, membentuk seperti mulut ikan (fish mouth deformity), seperti yang tampak pada gambar $10 .^{6,7}$ 


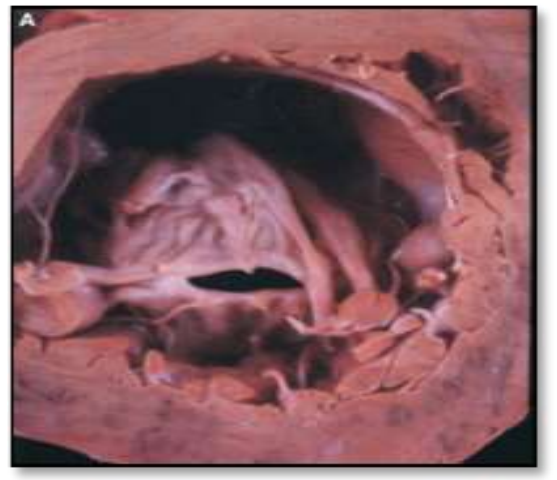

Gambar 10. Tampak penebalan katup, penebalan dengan fusi korda tendinea dan fish mouth deformity. ${ }^{6}$

\section{SIMPULAN}

Demam rematik akut merupakan penyebab karditis rematik yang ditandai dengan inflamasi pada katup sehingga terjadinya valvulitis yang terutama mengenai katup mitral. Proses inflamasi akut ini terjadi pada daun katup dan korda tendinea berupa penebalan daun katup karena edema, pemanjangan atau ruptur korda tendinea, dilatasi annulus, gangguan koaptasi katup sehingga menyebabkan regurgitasi katup.

Proses penyembuhan dari fase akut terjadinya neovaskularisasi, pembentukan jaringan granulasi dan fibrosis, kalsifikasi, fusi komisura, penebala daun katup, penebalan dan fusi korda tendinea sehingga menyebabkan daun katup kaku yang mengakibatkan stenosis pada katup.

\section{DAFTAR PUSTAKA}

1. WHO. Rheumatic fever and rheumatic heart disease: report of a WHO Expert Consultation, Geneva, 29 Oct-1 Nov 2001: Geneva; WHO Technical report series No.923; 2004;p1-65.

2. Soeroso S. Tinjauan prevalensi demam rematik dan penyakit jantung rematik pada anak di Indonesia. Semarang. Naskah Lengkap Simposium dan Seminar Kardiologi Anak.1986;5;1-11.

3. Levine R. A et all. Mitral valve disease, morphology and mechanisms. Nature reviews cardiology.2015;2-4.
4. Zwikker GL, Delemarre BJ, Huysmans HA. Mitral valve anatomy and morphology. Journal of cardiology surgery.1994;9;255-61.

5. Catherine M Oto, Bonow RO. Valvular Heart Disease, a companion to Braunwald's Heart Disease.2004;144756.

6. Jeffrey J, Silbiger, MD, Raveen B, MD. Contemporary Insights into the Functional Anatomy of the Mitral Valve. American Heart Journal. 2009;158(6):887-895.

7. Mann DL, Zipes DP, Libby P, Bonow RO. Mitral valve disease. Braunwald's Heart Disease. Textbook of cardiovascular medicine. 2015; 10; 1469-94.

8. Guilherme L, Cury P, Demarchi LMF, Coelho V, Abel L, Lopez AP et al. Rheumatic Heart Disease : Proinflammatory cytokines play a role in the progression and maintenance of valvular lesions. The American Journal of Pathology, 2004 ;165 ; 1583-91.

9. Carapertis J, Brown A, Maguire G, Walsh W. Diagnosis and management of acute rheumatic fever and rheumatic heart disease in Australia; National Heart Foundation of Australia; 2006; 50-59.

10. McCarthy KP, Ring L, Rana BS. Anatomy of the mitral valve: Understanding the mitral valve complex in mitral regurgitation. European Journal of Echocardiography. 2010;11:1-7

11. Barber JE, Kaspe FK, Ratliff NB, Cosgrove DM, Griffin BP, Vesely I. Mechanical properties of myxomatous mitral valves. Journal Thorac Cardiovascular Surgeon. 2001; 122: $955-62$.

12. Grande-Allen KJ, Calabro A, Gupta V, Wight TN, Hascall VC, Vesely I. Glycosaminoglicans and proteoglycans in normal mitral valve leaflets and chordae: association with regions of tensile and compressive loading. 
Glycobiology $2004: 14: 621-33$.

13. Roberts S, Kosanke S, Dunn ST, Jankelow D, Duran CMG,

Cunningham MW. Pathogenic mechanisms in rheumatic carditis : focus on valvular endothelium. Journal of infectious disease. $2001 ; 183$; 50711.

14. Wooley CF, Baker PB, Kolibash AJ, Kilman JW, Sparks EA, Boudoulas H. The floppy, myxomatous mitral valve, mitral valve prolapse, and mitral regurgitation. Prognosis Cardiovascular Disease 1991; 33: 397-433.

15. Cunningham MW. Streptococcus and rheumatic fever. Curr Opin Rheumatol. 2012. 24(4): 408-416

16. Allen, D Hugh et al. Moss and Adams'. Heart disease in infants, children, and adolescents. 2008; 62; 876-97.

17. Nevin M, Habeeb M. Iman s, Hadidi A. ongoing inflammation in children with rheumatic heart disease. Cardiology in the young. 2011; 21; 334-39.

18. Veinot JP. Pathology of inflammatory native valvular heart disease. Journal of Cardiovascular 2006;15;243-51.

19. Rajamannan NM et al. Calcified rheumatic valve neoangiogenesis is associated with vascular endothelial growth factor expression and osteoblast-like bone formation. Circulation. Journal Of American Heart Association. 2005; 111: 3296-301.

20. Deckers MM et al. Bone morphogenetic proteins stimulate angiogenesis through osteoblastderived vascular endothelial growth factor A. Endocrinology. 2002;143:1545-553. 